\title{
SAFETY OF RADIOGRAPHIC IMAGING IN PREGNANCY
}

\author{
Jelena Popić Ramač ${ }^{1}$, Verica Garaj Vrhovac², Vinko Vidjak¹, \\ Zoran Brnić ${ }^{3}$ and Barbara Radošević Babić ${ }^{1}$ \\ ${ }^{1}$ Department of Diagnostic and Interventional Radiology, Merkur University Hospital; \\ ${ }^{2}$ Institute for Medical Research and Occupational Health; ${ }^{3}$ Department of Diagnostic and Interventional Radiology, \\ Sestre milosrdnice University Hospital Center, Zagreb, Croatia
}

\begin{abstract}
SUMMARY - There are many false assumptions, both in the general population and among physicians, regarding the influence of radiation on pregnant patients and the fetus during diagnostic procedures, in spite of scientific facts based on studies. These false assumptions are mostly based on the idea that every diagnostic procedure using ionizing radiation is a cause for serious concern and that artificial abortion as a possible solution might be considered. We analyzed data from counseling of pregnant patients exposed to ionizing radiation during diagnostic procedures in the Merkur University Hospital during a 4-year period. In this period, 26 patients presented for counseling after exposure to diagnostic ionizing radiation during pregnancy. Results showed most of these patients to have been exposed to radiation between the $2^{\text {nd }}$ and $3^{\text {rd }}$ week of gestation $(36 \%)$, between the $4^{\text {th }}$ and $5^{\text {th }}$ week $32 \%$, before the $2^{\text {nd }}$ week $24 \%$, and after the $6^{\text {th }}$ week of gestation less than $8 \%$. To provide reasonable estimate of fetal doses, Report No. 174 from the National Council on Radiation Protection and Measurements (NCRP) was used. Data from the Report include estimate of the fetal dose from direct and indirect exposures. The mean doses were up to $0.01 \mathrm{cGy}$ in $46.2 \%, 0.01-0.15 \mathrm{cGy}$ in $19.2 \%, 0.2-1 \mathrm{cGy}$ in $26.9 \%$ and $1 \mathrm{cGy}$ or more in $7.7 \%$ of patients. None of the counseled patients had medical indication for abortion, even though in a small percentage of patients abortion was a personal subjective decision. Considering that there are no Croatian guidelines for counseling patients exposed to ionizing radiation during pregnancy, it is recommended to use the International Commission on Radiological Protection guidelines in the management of pregnant patients exposed to ionizing radiation.
\end{abstract}

Key words: Pregnancy - radiography; Pregnancy - radiation effects; Fetus - radiation effects; Radiation injuries; Abortion, induced

\section{Introduction}

There are many false assumptions, both in the general population and among physicians, regarding the influence of radiation on pregnant patients and the fetus during diagnostic procedures, in spite of scientific facts based on studies ${ }^{1,2}$. These false assumptions are mostly based on the idea that every diagnostic procedure using ionizing radiation is a cause for serious

Correspondence to: Assist. Prof. Jelena Popić Ramač, MD, Department of Diagnostic and Interventional Radiology, Merkur University Hospital, Zajčeva 19, HR-10000 Zagreb, Croatia E-mail: jelena.popic.ramac@gmail.com Received August 18, 2015, accepted November 19, 2015 concern and that artificial abortion as a possible solution should be taken into consideration. Deliberations regarding the possible influence of ionizing radiation on the pregnant patient and the fetus originate from the time when ionizing radiation in medical diagnostics was first used. Scientific information available to us is derived from animal studies and especially from studies of natural incidents (atomic bombings of Hiroshima and Nagasaki, accidents in nuclear power plants Chernobyl and Fukushima) $)^{3}$. Studies on pregnant patients are, of course, not allowed.

As physicians and radiologists, we often witness cases of unintentional exposure of female patients to 
diagnostic ionizing radiation, especially in the period when they may not yet be aware of their pregnancy. Often these patients return for counseling because they are afraid of possible repercussions on the fetus. This counseling is performed by the person in charge of radiation protection in every institution, and if it is a question of fluoroscopic exposure to radiation, assistance from a medical physicist is often requested, as well as to calculate the dose received.

Counseling is performed in terms of the possible risk $^{4,5}$. Absolute risk is the number of cases $/ 10^{6}$ population $/ \mathrm{mGy} /$ year. Relative risk is the number of persons with negative effects of radiation exposure in an exposed population/number of persons with the same effects in an unexposed population. Usually, the values average between 1 to 2 , and possibly more. An excess risk is difference in the incidence between an exposed and an unexposed population ${ }^{6,7}$. Speaking in risk terms, one must bear in mind that there are certain 'base' risks in healthy, unexposed pregnant women. These risks are approximately as follows: $15 \%$ risk of spontaneous abortion, $4 \%-10 \%$ risk of genetic malformations, $4 \%$ risk of intrauterine growth retardation, and $2 \%-4 \%$ risk for one of the major malformations. There are three important growth periods in which there is a possible influence of radiation on reproduction: influence on fertility before pregnancy in terms of possible reduced fertility; influence during pregnancy with possible fetal malformations; and influence after pregnancy with possible genetic defects. The influence of radiation in the period before pregnancy can cause reduced fertility due to damage to the gonads in both men and women. This represents a nonstochastic damage that has a clear relation to the dose and it will not occur under a certain threshold. Results of studies in this field are inconclusive, but they are also dependent on each body individual sensitivity ${ }^{8}$. Generally, doses above $0.26 \mathrm{mGy}$ are considered to cause temporary damage to spermatogenesis in men and doses above 3 $\mathrm{mGy}$ cause permanent sterility in women ${ }^{9,10}$. It is important to mention two large studies performed on American radiologists in 1927 and 1955, which have significantly contributed to our understanding of the influence of radiation exposure on fertility. Radiation exposure of either parent before pregnancy does not increase the incidence of fetal malformations. This fact is derived from the studies on atomic bomb survivors, as well as on parents that were treated by radiotherapy as children ${ }^{11,12}$.

\section{Patients and Methods}

We analyzed data from counseling of patients exposed to ionizing radiation during their pregnancy at the Merkur University Hospital during a 4-year period. During this period, 26 patients presented for counseling after exposure to ionizing radiation during pregnancy. Counseling was always performed by the person in charge of radiation protection, a physician with specialization in radiology. Dose exposure was dependent on the device used for imaging but also on the imaging procedures, so calculation of the dose received was most precise if calculated for each device individually. In some cases, the dose was calculated with the help of a medical physicist when interventional procedures were performed.

\section{Results}

Study results showed that during the study period, counseling was requested by $3.8 \%, 19.2 \%, 26.9 \%$, $34.6 \%, 11.5 \%$ and $3.8 \%$ of pregnant patients aged $\leq 20$, $20-24,25-29,30-34,35-39$ and $\geq 40$, respectively. The results are in accordance with the general trend of increasing age at pregnancy. The mean age of our patients was $29.1 \pm 5.8$ years (Fig. 1 ).

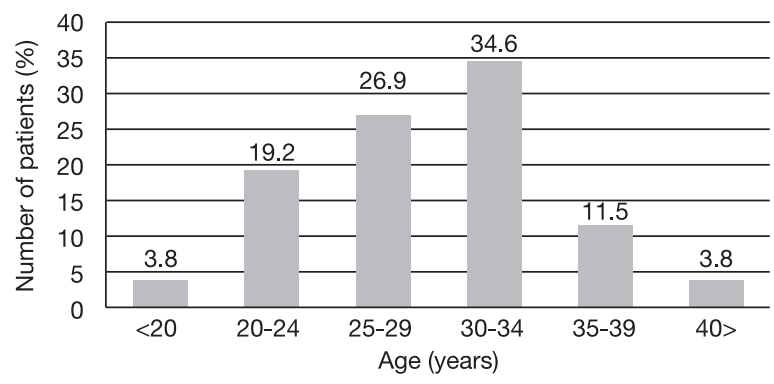

Fig. 1. Age of patients at the time of imaging.

According to the number of previous deliveries, counseling was approached by $46.2 \%$ of primiparae, $38.5 \%$ of secundiparae and $15.4 \%$ of tertiparae (Fig. 2).

According to gestational age at the time of irradiation, $24 \%$ of women were in less than the $2^{\text {nd }}$ week, $36 \%$ between the $2^{\text {nd }}$ and $3^{\text {rd }}$ week, $32 \%$ between the $4^{\text {th }}$ and $5^{\text {th }}$ week, and $8 \%$ in the $>6^{\text {th }}$ week of gestation. The mean gestational age of our patients was $3.4 \pm 2.6$ weeks (Fig. 3). 


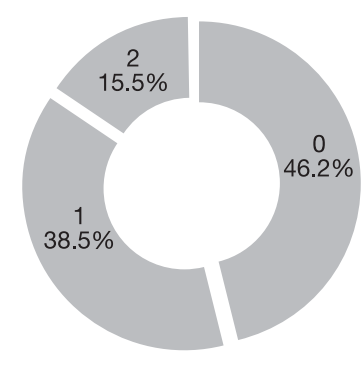

Fig. 2. Number of previous deliveries.

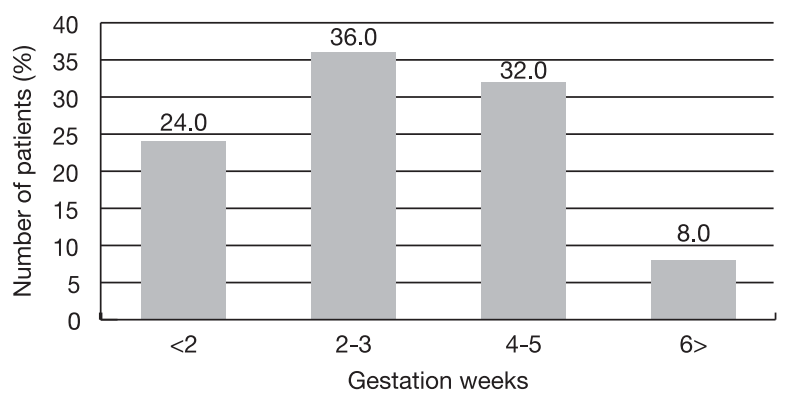

Fig. 3. Gestational age at the time of irradiation.

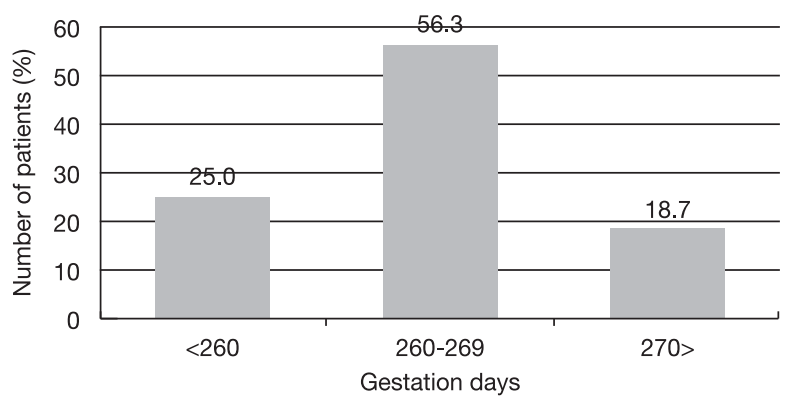

Fig. 4. Gestational age at birth.

According to gestational age at delivery, 25\% of women gave birth after $\leq 260$ days of gestation, $56.3 \%$ after 260-290 days of gestation, and 18.7\% after $\geq 270$ days of gestation (Fig. 4). The mean duration of pregnancy (on the day of delivery) was $262 \pm 12.3$ days, range 237-294 (34-42 weeks).

Figure 5 shows that there was negative $(r=-0.173)$ correlation between fetal dose and gestational age at birth. The correlation ( $p=0.534$ ) was of borderline significance. One measurement (35 cGy) was ruled out from these calculations as an outlier.

The mean dose in pregnant women was as follows: $\leq 0.01$ cGy in $46.2 \%, 0.01-0.15$ cGy in $19.2 \%, 0.2-1$ $\mathrm{cGy}$ in $26.9 \%$, and $\geq 1 \mathrm{cGy}$ in $7.7 \%$ of women. The mean fetal dose was $1.6 \pm 6.8 \mathrm{cGy}$.

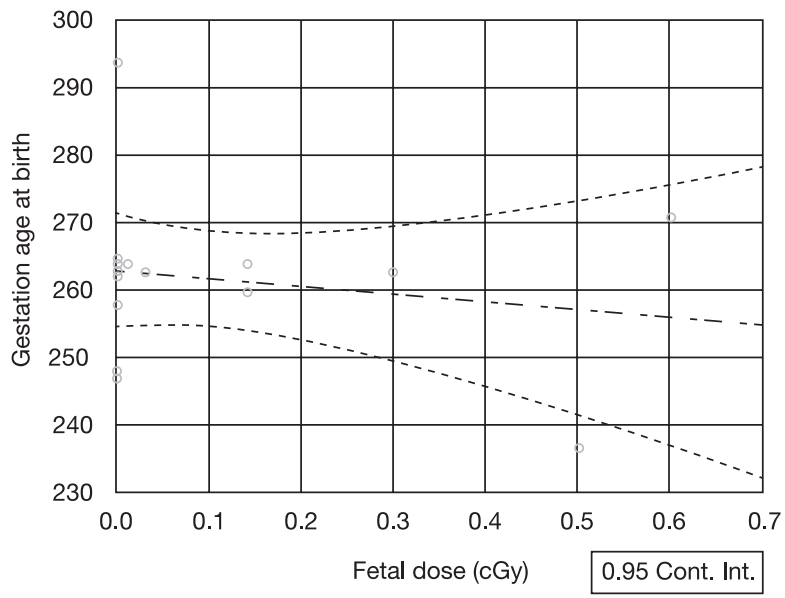

Fig. 5. Correlation of gestational age at birth with fetal dose.

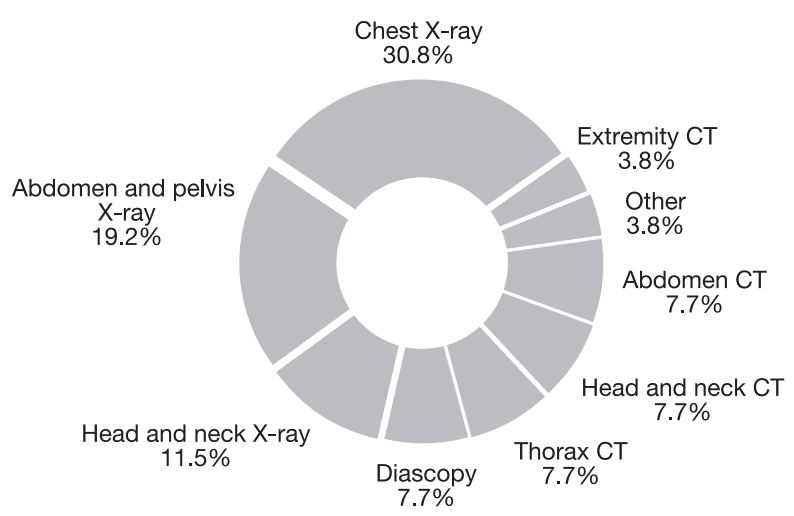

Fig. 6. Imaging categories.

Recommendation for artificial termination of pregnancy was not found medically justified in none of study women. The decision to keep pregnancy was subjective in $93.3 \%$ of cases, whereas $6.7 \%$ of women decided on their own to terminate pregnancy in spite of advice to keep pregnancy.

Looking at the categories of imaging performed, there were $30.8 \%$ of standard chest $\mathrm{x}$-rays, $19.2 \%$ of standard abdominal and pelvic $\mathrm{x}$-rays, $11.5 \%$ of standard head and neck x-rays, $7.7 \%$ of fluoroscopic examinations, $7.7 \%$ of abdominal computed tomography (CT) scans, $7.7 \%$ of head and neck CT scans, $7.7 \%$ of thoracic CT scans, $3.8 \%$ of extremity CT scans, and $3.8 \%$ of other imaging techniques (Fig. 6).

The gonads were within the primary beam in $38.5 \%$ of cases, whereas in $61.5 \%$ of cases they were outside the primary $\mathrm{x}$-ray beam. The mean fetal dose with gonads outside the primary beam was $0.023 \pm 0.047 \mathrm{cGy}$, 
whereas in cases with gonads within the primary beam the mean fetal dose was $0.805 \pm 1.051 \mathrm{cGy}$, yielding a statistically significant difference $(p=0.001)$.

\section{Discussion}

Radiation exposure related risks during pregnancy (in utero) are dependent on gestational age at the time of imaging and the dose absorbed. The risks are greatest at the time of organogenesis and in the early fetal period, and somewhat lower in the second and third trimester $^{2,8}$.

In the first two weeks of conception or during two weeks after the absence of expected menstrual period, the embryo is very resistant to $\mathrm{x}$-rays. It is sensitive to lethal influences at doses of $50 \mathrm{mSv}$. Between the $3^{\text {rd }}$ and $8^{\text {th }}$ week of pregnancy, at doses below $200 \mathrm{mSv}$ the embryo is not subject to anomalies, abortion or growth retardation. Between the $8^{\text {th }}$ and $15^{\text {th }}$ week, the embryo/fetus is sensitive to radiation effects on the central nervous system (CNS) if it is above $300 \mathrm{mSv}$. After the $20^{\text {th }}$ week, it is resistant to growth influences and no more sensitive than the mother. There is no sensitivity to doses within the diagnostic range ${ }^{13,14}$.

All radiation effects in pregnancy are stochastic, meaning that there is no safe threshold below which they are not possible. Teratogenic effects are not passed on to the next generation, while the genetic ones are. The most important possible radiation effects in pregnancy include prenatal death, neonatal death, congenital anomalies, malignant diseases, growth retardation/

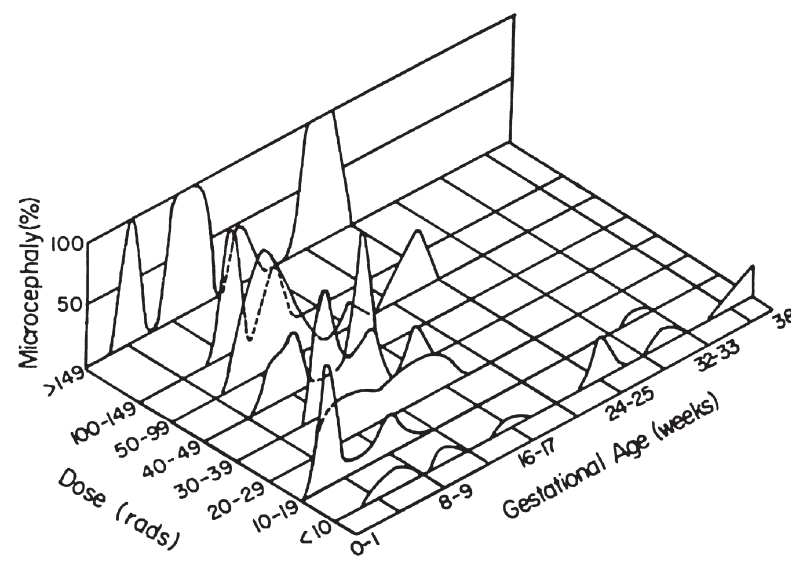

Fig. 7. Incidence of microcephaly relative to dose and gestational age as a result of in utero exposure to radiation in atomic bomb survivors ${ }^{24}$. anomalous growth, genetic affects, and mental retardation $^{15,16}$. CNS damage is most likely with radiation exposure between the $8^{\text {th }}$ and $25^{\text {th }}$ week of gestation because it is the period when it is most susceptible to radiation damage. Fetal doses exceeding $100 \mathrm{mGy}$ can cause reduction in the intelligence quotient. Fetal doses of $1000 \mathrm{mGy}$ can cause mental retardation and microcephaly, especially in the $8^{\text {th }}$ to $15^{\text {th }}$ week, and somewhat reduced mental retardation from the $16^{\text {th }}$ to $25^{\text {th }}$ week $^{17,18}$.

As previously mentioned, there is no safe threshold for in utero radiation damage, but it is considered that this dose ranges around 100-200 mGy. These doses can cause CNS damage.

It should be mentioned that fetal doses of 100 $\mathrm{mGy}$ are not delivered even with 3 pelvic CT examinations or $20 \mathrm{x}$-ray images, but fluoroscopy guided interventional procedures are potentially dangerous, as well as radiotherapy because they can attain much larger doses ${ }^{15,17}$.

The possibility of leukemia induction and carcinogenic effects presents great concern. It is well known that exposure to radiation increases the risk of developing leukemia and certain types of cancer in children and adults, mostly thyroid, breast and lung cancer. When using the term risk, it is important to differentiate the relative and absolute risk. The term relative risk means the number of cases with some effect of radiation among exposed population divided by the number of cases with the same effect among non-exposed population. The exact number would be the absolute risk, which means the number of cases $/ 10^{6}$ persons $/ \mathrm{mGy} /$ years, but it can only be calculated from epidemiological long-term studies such as studies of natural incidents ${ }^{3}$.

During the pregnancy period after organogenesis, the embryo/fetus is exposed to the same carcinogenic risks as a child would be. In this sense, the work by a British pediatrician Alice Stewart ${ }^{18-20}$ who studied 9000 cases of leukemia in an irradiated population and almost the same number in a control group is exceptionally important. Results of this and similar studies have produced the risk calculation for leukemia displayed in Table $1^{20}$.

The relative risk of leukemia can be high and it is 1.4 (40\% higher than the standard risk incidence) with fetal doses of $10 \mathrm{mGy}$. The absolute risk of developing cancer for a person exposed to radiation of $10 \mathrm{mGy}$ in 
Table 1. Relative risk of developing leukemia in children exposed to radiation ${ }^{21}$

\begin{tabular}{|l|c|}
\hline Time of exposure & Relative risk \\
\hline First trimester & 8.3 \\
Second trimester & 1.5 \\
Third trimester & 1.4 \\
Total & 1.5 \\
\hline
\end{tabular}

Table 2. Probability of giving birth to a healthy child related to radiation dose $e^{17}$

\begin{tabular}{|c|c|c|}
\hline $\begin{array}{c}\text { Fetal dose } \\
\text { (mGy) above } \\
\text { background } \\
\text { radiation }\end{array}$ & $\begin{array}{c}\text { Probability of } \\
\text { fetus without } \\
\text { malformations }\end{array}$ & $\begin{array}{c}\text { Probability } \\
\text { of child with } \\
\text { no cancer } \\
\text { (age 0-19) }\end{array}$ \\
\hline 0 & 97 & 99.7 \\
1 & 97 & 99.7 \\
5 & 97 & 99.7 \\
10 & 97 & 99.6 \\
50 & 97 & 99.4 \\
100 & 97 & 99.1 \\
$>100$ & Possible & Higher \\
\hline
\end{tabular}

Table 3. Mean dose per examination

\begin{tabular}{|l|c|c|}
\hline \multirow{2}{*}{ Data from the UK ${ }^{24}$} & \multicolumn{2}{|c|}{} \\
\hline \multirow{2}{*}{ Examination } & \multicolumn{2}{|c|}{ Dose (mGy) } \\
\cline { 2 - 3 } & $\begin{array}{c}\text { Mean } \\
\text { (mGy) }\end{array}$ & $\begin{array}{c}\text { Maximum } \\
(\mathrm{mGy})\end{array}$ \\
\hline Barium meal (UGI) & 1.1 & 5.8 \\
Barium enema & 6.8 & 24 \\
Head CT & $<0.005$ & $<0.005$ \\
Chest CT & 0.06 & 1.0 \\
Abdomen CT & 8.0 & 49 \\
Pelvis CT & 25 & 80 \\
Abdomen & 1.4 & 4.2 \\
Chest & $<0.01$ & $<0.01$ \\
Intravenous urogram; & 1.7 & 10 \\
lumbar spine & 1.1 & 4 \\
Pelvis & $<0.01$ & $<0.01$ \\
Skull; thoracic spine & & \\
\hline
\end{tabular}

utero is 1 death from carcinoma in $0-15$ years/ 1700 . Table 2 illustrates the probability of having a healthy child in relation to radiation dose, showing that only doses above $100 \mathrm{mGy}$ reduce the probability of a fetus without malformations. The probability of a child cancer free up to the age of 19 years is decreased minimally even with doses above $10 \mathrm{mGy}$, somewhat more with increasing doses ${ }^{15,17}$.

Unwanted radiation effects are dose dependent, particularly dependent of fetal doses. To calculate that dose, it is necessary to have information on the duration of pregnancy, anatomical characteristics of the patient and imaging techniques used, as well as on the radiation protection devices used. However, basically, the fetal dose matches closely the dose to the uterus ${ }^{21,22}$.

To get an approximate value of the fetal dose on particular imaging examinations, one must understand the devices and imaging techniques used. The mean doses are displayed in Table 3 (data from Great Britain $)^{23}$.

\section{Conclusion}

When dealing with irradiation of pregnant women in Croatia, one must abide by the Act on Radiation Protection and Safety of Ionizing Radiation Sources (Official Gazette 141/13 and 39/15) and use the International Commission on Radiological Protection (ICRP) guidelines.

When exposing women in their generative age to ionizing radiation, one must always assess the possibility of pregnancy. Any delay in menstrual cycle must be considered as pregnancy until proven otherwise. $\mathrm{Pa}-$ tient waiting rooms must have a written warning clearly stating: "If there is a chance of pregnancy please inform the physician or technician before imaging or application of contrast media".

All medical procedures (on the environment or a patient) must be justified (benefit greater than risk). Before performing a medical procedure, justification of the procedure must be verified. After a certain procedure has been decided on, the respective fetal dose must be reduced as much as possible.

Pregnant women (patients or professionals) have the right to be informed on the amount and type of potential radiation effects that might occur upon in utero exposure to radiation. In communication with such persons, the risks should be stated. Risks are negligible in low-dose protocols ( $<1 \mathrm{mGy}$ on fetus). If fetal doses exceed $1 \mathrm{mGy}$, additional counseling is necessary. 
According to the Croatian Act on Radiological and Nuclear Safety, it is defined that:

Article 26

(1) The bearer of the license for performing activities with sources of ionizing radiation or nuclear activities must provide a workplace where effective dose does not surpass $1 \mathrm{mSv}$ per year for exposed employees during their pregnancy.

(2) Breast-feeding employees may not work in workplaces with the possibility of radiation pollution.

Radiotherapy and interventional procedures under fluoroscopic guidance may cause fetal doses of 10-100 $\mathrm{mGy}$ or higher, depending on the procedure. After these procedures, fetal dose and potential risk must be calculated (medical physicist).

Based on our experience, in practice it is advisable to follow ICRP (Report 174) recommendations for counseling pregnant patients ${ }^{2}$ :

1. In fetal doses up to $1 \mathrm{mGy}$ keep the pregnancy and explain the risks in comparison to the risks from natural sources.

2. In fetal doses ranging from 10 to $50 \mathrm{mGy}$ follow the 'wait and see' rule. Use all diagnostic methods for early detection of anomalies (cytology, ultrasound, etc.).

3. In fetal doses of 50-100 mGy, if there are no additional risk factors (history, heritage, smoking, alcohol abuse, drugs, etc.), use the 'wait and see' rule; if there are additional risk factors, the recommendation for medical termination of pregnancy may be justified.

4. In fetal doses of 100-250 mGy, the recommendation is termination of pregnancy, unless both parents accept the risks of physical and mental anomalies and early leukemia.

5. In fetal doses of $250 \mathrm{mGy}$ and above, the recommendation is unconditional termination of pregnancy (in view of a very high probability of severe anomalies or mental retardation).

\section{References}

1. Parry RA, Glaze SA, Archer BR. Typical patient radiation doses in diagnostic radiology. Radiographics. $1999 \mathrm{Sep}-\mathrm{Oct} ; 19$ (5):1289-302.

2. Report No 174: Preconception and prenatal exposure: health effects and protective guidance. National Council on Radiation Protection and Measurements [Internet]. 2013. [cited 2015
October 12]; available at: www.ncrponline.org/Publications/174press

3. Pierce DA, Preston DL. Radiation-related cancer risks at low doses among atomic bomb survivors. Radiat Res. 2000;154: 178-86.

4. Brenner DJ, Elliston CD. Estimated radiation risks potentially associated with full-body CT screening. Radiology. 2004; 232:735-8.

5. Hurwitz LM, Yoshizumi TT, Reiman RE, et al. Radiation dose to the female breast from 16-MDCT body protocols. AJR Am J Roentgenol. 2006;186:1718-22.

6. Khursheed A, Hillir MC, Shrimpton PC, Wall BF. Influence of patient age on normalized effective doses calculated for CT examinations. Br J Radiol. 2002;75:819-30.

7. Hall EJ. Lessons we have learned from our children: cancer risks from diagnostic radiology. Pediatr Radiol. 2002;32:700-6.

8. Bushong S. Radiologic Science for Tehnologists. $9^{\text {th }}$ ed. 2011; 429-523.

9. Vock P, Soucek M, Daepp M, Kalender WA. Lung: spiral volumetric CT with single-breath-hold technique, continuous transport, and scanner rotation. Radiology. 1990;176:864-7.

10. Clemons M, Loijens L, Gross P. Breast cancer risk following irradiation for Hodgkin's disease. Cancer Treat Rev. 2000; 26:291-302.

11. Baranov AE, Guskova AK, Nadejina NM, Nugis V. Chernobyl experience: biological indicators of exposure to ionising radiation. Stem Cells. 1995 May;13 Suppl 1:69-77.

12. Kumagai E, Tanaka R, Kumagai T, Onomichi M, Sawada S. Effects of long-term radiation exposure on chromosomal aberration in radiological technologist. J Radiat Res. 1990Sep;31 (3):270-9.

13. Nadich DP, Marhall CH, Gribbin C, Arams RS, Mc Cauley DI. Low-dose CT of the lungs: preliminary observations. Radiology. 1900;175:729-31.

14. UNSCEAR 2000 Medical Radiation Exposures. United Nations Scientific Committee on the Effects of Atomic Radiation Report to the General Assembly [Internet] 2006 [cited 2015 October 12]. Available at: http://cnts.wpi.edu/RSH/Docs/ UN-Chernobyl/inex.html

15. European Commission [Internet] European Union, 19952015. [updated 2015 Oct 12; cited 2015 Oct 12]. Radiationprotection-series-publications. available at: https://ec.europa. eu/energy/en/radiation-protection-series-publications

16. International Atomic Energy Agency [Internet] IAEA 19982014. [updated 2015 Oct 12; cited 2015 Oct 12]. Available at: http//www.iaea.org

17. International Commission on Radiological Protection [Internet] ICRP 2002-2015. [updated 2015 Sept 28; cited 2015 Oct 12]. Available at: http// http//www.icrp.org

18. Stewart A, Kneale GW. Radiation dose effects in relation to obstetric X-rays and childhood cancers. Lancet. 1970;1:1185-8. 
19. Giles D, Hewitt D, Stewart A, Webb J. Malignant disease in childhood and diagnostic irradiation in utero. Lancet. 1956 Sep 1;271(6940):447.

20. Stewart A, Webb D, Hewitt D. A survey of childhood malignancies. BMJ. 1958;1:1495-508.

21. United Nations Scientific Committee on the Effects of Atomic Radiation [Internet] UNSCEAR 2002-2015[updated 2014 Dec; cited 2015 Oct 12]. Available at: http//www.unscear.org
22. World Health Organization [Internet] WHO 2015. [updated 2015 Oct 12; cited 2015 Oct 12]. Available at: http// www.who.int

23. Hart D, Wall BH. National Radiological Protection Board, Childton, Didchot, Oxon [Internet]. 2002. [cited 2015 October 12]. Available at: http//cloud.medicalphysicist.co.uk/nrpb_ w4.pdf

24. www.icrp.org/docs/icrp_84-pregnncy_s.pps.

Sažetak

\section{RADIOLOŠKA SNIMANJA U TRUDNOĆI}

\section{J. Popić Ramač, V. Garaj Vrhovac, V. Vidjak, Z. Brnić i B. Radošević Babić}

Usprkos znanstvenim spoznajama temeljenim na dugogodišnjim studijama utjecaja zračenja u dijagnostičke svrhe na trudnicu i plod o toj temi vladaju zablude kako u općoj populaciji tako i među liječnicima. Te se zablude odnose uglavnom na razmišljanje o svakoj dijagnostičkoj pretrazi koja rabi ionizirajuće zračenje kao o razlogu za ozbiljnu zabrinutost i razmatranje artificijelog pobačaja kao mogućeg rješenja. Analizirali smo podatke savjetovanja trudnica ozračenih u dijagnostičke svrhe u KB Merkur kroz razdoblje od 4 godine. U tom razdoblju savjetovalo se 26 trudnica ozračenih u dijagnostičke svrhe u našoj ustanovi. Rezultati su pokazali da je najveći broj trudnica, njih 36\%, ozračen između 2. i 3. tjedna gestacije, između 4. i 5. tjedna 32\%, do 2. tjedna 24\%, a iznad 6. tjedna gestacije njih manje od 8\%. Za izračun fetalnih doza korišten je Izvještaj 174 Nacionalnog vijeća za zaštitu od zračenja i mjerenja zračenja. Podaci iz izvještaja omogućuju procjenu doze izračun koje uzima u obzir izravnu i neizravnu izloženost za sve postupke. Prosječne doze bile su: do 0,01 cGy kod 46,2\%; 0,01-0,15 cGy kod 19,2\%; 0,2-1 cGy kod 26,9\%; 1 cGy i više kod 7,7\% trudnica. Niti jedna savjetovana trudnica nije imala medicinsku indikaciju za pobačaj, makar je u malom postotku slučajeva pobačaj bio osobna subjektivna odluka. S obzirom na to da ne postoje hrvatske smjernice za savjetovanje trudnica ozračenih u dijagnostičke svrhe preporuka je koristiti smjernice ICRP vezane za medicinske indikacije pobačaja kod određenih doza zračenja.

Ključne riječi: Trudnoća - radiografja; Trudnoća - radijacijski učinci; Fetus - radijacijski učinci; Radijacijske ozljede; Abortus, inducirani 